\section{Original Article}

Neonatal Med 2015 February;22(1):21-26

http://dx.doi.org/10.5385/nm.2015.22.1.21

pISSN 2287-9412 . eISSN 2287-9803 neonatal
medicine

\title{
Presentation Time of Necrotizing Enterocolitis Diagnosed by Sonography according to Gestational Age
}

So Hyun Kim, M.D., Joo Hyung Park, M.D., Chung Joon Moon, M.D., Gye-Yeon Lim, M.D.*, and So Young Kim, M.D.

Departments of Pediatrics, Radiology*, School of Medicine, The Catholic University of Korea, Seoul, Korea

\section{ABSTRACT}

Purpose: In this single center study, we assessed the timing of presentation of necrotizing enterocolitis (NEC) diagnosed by sonography according to the gestational age. Methods: We retrospectively reviewed the medical records of 49 newborn patients who were diagnosed with NEC (modified Bell's stage II and higher according to abdominal sonography and simple abdominal radiography) and were admitted to the neonatal intensive care unit of St. Mary's Hospital between January 2008 and December 2012. Infants were grouped according to their gestational age (GA): Group I (GA<28 weeks), Group II (GA, 28-32 weeks), Group III (GA, 33-36 weeks), and Group IV ( $G A \geq 37$ weeks); early-onset NEC was considered when NEC developed at $<14$ days of age and late-onset NEC was considered when NEC developed at $\geq 14$ days of age. Results: The number of infants in each group were: Group I ( $n=16)$, Group II ( $n=20)$, Group III ( $\mathrm{n}=11)$, and Group IV ( $\mathrm{n}=2)$. The mean age at diagnosis of NEC was: Group I (31.6 days), Group II (15.9 days), Group III (11.0 days), and Group IV (2.0 days). Early-onset NEC developed at a mean of 5.5 days of age, whereas late-onset NEC developed at a mean of 36.1 days of age

Conclusion: Based on early sonographic diagnosis, infants with lower gestational ages developed NEC at a more advanced postnatal age as compared to more mature infants. However, further studies are needed to understand the etiology of this disease process.

Key Words: Newborn, Necrotizing enterocolitis, Ultrasonography, Diagnosis, Epidemiology

서론

신생아 괴사성 장염(necrotizing enterocolitis, NEC)은 신생아 중환자실에서 발생하는 가장 흔한 장관 질환 중 하나로 발생 빈도는 신생아 중환자실 입원 환자의 $1-5 \%$ 이나 신생아 집중 치료를 필요로 하는 대상 미숙아가 점차 증가하면서 이에 이환되는 환자의 수가 증가하고 있 다 ${ }^{1-5)}$. NEC는 다양한 인자에 의해 발생하는 것으로 추정되며, 조기 진단이 어려운 중증 질환
Received: 25 July 2014

Revised: 22 October 2014

Accepted: 23 October 2014

Correspondence to:

So Young Kim, M.D.

Department of Pediatrics, Yeouido St. Mary's Hospital, School of Medicine, The Catholic University of Korea 62 Yeouido-dong, Yeongdeungpogu, Seoul 150-713, Korea

Tel: +82-2-3779-1206

Fax: +82-2-783-2589

E-mail: sykimped@catholic.ac.kr
Copyright(c)

By Korean Society of Neonatology.

All right reserved.

This is an Open-Access article distributed under the terms of the Creative Commons Attribution Non-Commercial License (http://creativecommons.org/licenses/ by-nc/3.0), which permits unrestricted non-commercial use, distribution, and reproduction in any medium, provided the original work is properly cited. 
으로서 높은 사망률을 보이고 있다). 발생 원인으로는 출생 시 재 태연령이 어린 것과 체중이 가벼운 것이 가장 중요한 원인으로 생 각되고 있으나 그 외 유전적 소인이나 감염, 빠른 수유의 진행, 세 균 감염 등 다양한 요인들이 복합되어 있는 것으로 알려져 있다 ${ }^{1,2)}$.

$\mathrm{NEC}$ 의 진단과 치료는 임상 양상과 혈액검사, 방사선 소견을 바 탕으로 한 Modified Bell's staging criteria ${ }^{7.8)}$ 를 바탕으로 이루어지 고 있다. 그러나 임상 양상의 경우 비특이적인 여러 증상이 다양한 정도로 나타날 수 있어 객관적인 진단이 조기에 이루어지기 어려 우며, 방사선학적 검사 중 주로 이용되고 있는 복부 단순 방사선검 사에서는 NEC진단의 결정적인 단서를 제공하는 장벽 내 공기 (pneumatosis intestinalis)를 확인하는 것이 어렵다9-11). 따라서 $\mathrm{NEC}$ 의 특징적인 소견들인 장벽 내 공기 및 문맥정맥 내 공기 (portal venous gas)를 보다 정확하게 관찰할 수 있는 복부 초음파 를 $\mathrm{NEC}$ 의 진단에 조기에 적극적으로 도입하고자 하는 연구 결과 들이 보고되고 있다 ${ }^{12-14)}$. 또한 NEC는 진단이 늦어지는 경우 사망 률이 $60 \%$ 에 달하는 질환으로 조기진단을 위하여 발생 원인 및 시 기를 미리 예측할 수 있는 방법에 대한 연구들도 진행되고 있다 15,16). 이에 저자들은 신생아 중환자실에 입원한 신생아들 중 복부 팽만 및 수유장애 등 NEC 가 의심되는 증상을 보인 신생아들의 진 단을 위하여 증상 초기부터 복부 초음파를 시행하여 $\mathrm{NEC}$ 를 진단 하였으며 복부 초음파를 통하여 진단된 NEC 환자들이 재태주령 에 따라 진단 시기에 어떤 차이가 있는지를 알아보고 NEC 진단 시 점에 따른 환자들의 임상 양상에 어떠한 특징이 있는지 알아보고 자 하였다.

\section{대상 및 방법}

\section{1. 대상}

2008년 1월부터 2012년 12월 까지 가톨릭대학교 여의도 성모 병원의 신생아 중환자실에 입원한 신생아들 중 복부팽만 및 수유 진행이 어려운 환자 등 괴사성 장염이 의심되어 감별이 필요했던 총 511명 환자들에게 복부 초음파를 시행하였으며 복부 초음파 결과를 modified Bell's criteria ${ }^{7,8)}$ 에 적용하여 NEC stage IIA 이상 에 해당하는 경우 $\mathrm{NEC}$ 로 진단하였고 초음파 상 $\mathrm{NEC}$ 로 진단된 환 자 49명을 대상으로 신생아 중환자실 기록을 후향적으로 분석하 였다.

\section{2. 방법}

복부 초음파를 통한 NEC 진단은 장마비, 장벽 내 공기, 문맥정 맥 내 공기, 복수(ascites), 복강 내 기복(pneumoperitoneum) 등 의 초음파 소견을 근거로 하였으며 특히 장벽 내 공기 및 문맥정맥 내 공기를 보이는 경우 방사선 소견 단계(radiologic finding stage)
$\mathrm{IA}$ 이상인 $\mathrm{NEC}$ 로 진단하였다. 복부 초음파는 한 명의 영상의학과 전문의가 시행하였다.

$\mathrm{NEC}$ 로 진단된 환자들은 재태주령을 기준으로 28 주 미만(1군), 28-32주(2군), 33-36주(3군), 37주 이상(4군)의 네 군으로 분류 하여 각 재태주령별 NEC발생 시기를 조사하였다. 또한 대상 환자 들을 NEC 발생 시기를 기준으로 조기발생 군(Early-onset NEC, $<14$ days) 및 후기발생 군(Late-onset NEC, $\geq 14$ days)으로 분류 하여 두 군의 특징을 조사하였다. 임상 증상에서 수유곤란(feeding intolerance)은 장관영양 시 다량의 위 잔류(gastric residue)와 역류(regurgitation) 및 구토 등으로 장관영양이 감소하거나 늦어 지는 증상이 있는 경우로 정의하였고, 복부팽만을 주로 보였던 경 우와는 따로 구분하였다. 동맥관 개존증(patent ductus arteriosus, $\mathrm{PDA})$ 은 진단 후 약물이나 수술적 치료 중 적어도 한 가지를 시행 한 경우로 정의하였고 패혈증은 균 배양 검사상 균이 동정된 경우 로 정의하였다. 뇌실 내 출혈(intraventricular hemorrhage, IVH) 의 정의와 중증도는 Papile 등17)의 분류에서 참고하였다.

\section{3. 통계분석}

통계분석은 SPSS 10.0.7 (SPSS Inc., Chicago, IL, USA)를 이용하 였으며 조기발생 군과 후기발생 군의 차이는 연속형 변수는 Mann-Whitney test 방법으로, 범주형 변수는 chi-square test 또는 Fisher's exact test로 비교하였으며 독립적인 예측 인자들을 분석 하기 위해 다중 회귀분석(multivariant logistic regression analysis) 을 사용하였다. 모든 분석에서 $P$ 값이 0.05 미만일 때 통계적으로 유의한 것으로 간주하였으며 관찰 값은 평균士표준 편차로 제시 하였다.

결과

\section{1. 대상아의 일반적인 특성}

2008년 1월 부터 2012년 12월 까지 신생아 중환자실에 입원한 환자들 중 511명에게 복부 초음파를 시행하였고 NEC stage IIA 이 상으로 진단을 받은 환자는 총 49 명으로 약 $9.6 \%$ 였다. 이들의 특 징은 평균 재태주령 $30.2 \pm 3.7$ 주 이며, 평균 몸무게는 $1,331.0 \pm$ $582.9 \mathrm{~g}$ 이었다. 성별은 남아가 22명, 여아가 27명이었고 진단 시 평균 일령은 $18.0 \pm 20.8$ 일 이었다. 출생방법은 자연분만이 22 명, 제왕절개가 27명이었으며 분만 장소는 Inborn이 44명이었다, 인 공호흡기를 사용한 환자는 27 명이었으며 초기 증상은 호흡곤란이 24 명(49.0\%), 혈변이 8명(16.3\%), 수유곤란이 25명(51.0\%), 복부 팽만이 43명(87.8\%), 무호흡증이 23명(49.6\%)에서 보였다. NEC 로 인한 수술은 2 명 $4.0 \%)$ 에서 시행되었으며 한 명은 33주 6일 출 생아, 다른 한 명은 27 주 출생아로 괴사성 장염으로 진단된 후 장 
천공이 진행되어 수술을 시행하였다. NEC로 인해 사망한 환자는 1 명 $(2.0 \%)$ 으로, 수술 환자 중 27 주 출생한 환자였다(Table 1).

\section{2. 재태주령 그룹에 따른 나이, 몸무게, 진단 시 재원일 비교}

재태주령 그룹은 28 주 미만이 16명이었고, 28 주에서 32 주가 20 명, 33 주에서 36 주가 11 명, 37 주 이상이 2명이었다. 각 그룹별 출 생체중은 28주 미만 평균 $822.5 \mathrm{~g}, 28-32$ 주 평균 1,278.0 g, 33-36 주 평균 $1,894.5 \mathrm{~g}, 37$ 주 이상 평균 $2,830.0 \mathrm{~g}$ 이었다. 진단 시 일령 은 28주 미만 평균 31.6일, 28-32주 평균 15.9일, 33-36주 평균 4.7 일, 37 주 이상 평균 3.5 일 이었다. 진단 시 월경 후 주령은 28 주 미만 평균 30.8주, 28-32주 평균 32.6주, 33-36주 평균 34.8주, 37 주 이상 평균 39.8 주 이었다(Table 2).

Table 1. Characteristics of Infants Diagnosed with Necrotizing Enterocolitis by Using Abdominal Sonography

\begin{tabular}{lc}
\hline Parameter & Values, $\mathrm{n}(\%)$ \\
\hline Gestational age (wks)* & $30.2 \pm 3.7$ \\
Body weight (g) & $1,331.0 \pm 582.9$ \\
Gender & \\
$\quad$ Male & $22(44.9)$ \\
Female & $27(55.1)$ \\
Delivery & \\
Cesarean delivery & $27(55.1)$ \\
Vaginal delivery & $22(44.9)$ \\
Age at diagnosis (d)* & $18.0 \pm 20.8$ \\
Respiratory distress & $24(49.0)$ \\
Ventilator care & $27(55.1)$ \\
Clinical symptoms & \\
Bloody stool & $8(16.3)$ \\
Feeding intolerance & $25(51.0)$ \\
Apnea & $23(49.6)$ \\
Abdominal distension & $43(87.8)$ \\
Surgery & \\
Death due to NEC & $2(4.0)$ \\
\end{tabular}

*Mean \pm SD.

${ }^{\dagger}$ Surgery: intestinal perforation closure.

Abbreviation: NEC, necrotizing enterocolitis.

\section{3. 출생 조기에 발생한 NEC 환자와 후기에 발생한 환자의 임상적 차이}

진단 시 일령에 따라 두 그룹으로 나누어 출생 14 일 이내 NEC 가 발병한 경우를 조기발생 군(Early-onset NEC), 출생 14일 이후 에 NEC 가 발생한 경우를 후기발생 군(Late-onset NEC)으로 정 의하였으며 총 49 명 중 조기발생 군은 29 명 $(59.2 \%)$, 후기발생 군 은 20명(40.8\%)이었다. 진단 시 평균 일령은 조기발생 군이 5.6일, 후기발생 군이 36.1 일 이었다. 두 그룹의 출생 시 평균 재태주령은 조기발생 군이 32.1 주, 후기발생 군이 27.4 주로 유의한 차이를 보 였다 $(P<0.001)$. 평균 출생 체중은 조기발생 군이 $1,534.1 \mathrm{~g}$, 후기발 생 군이 $1,036.5 \mathrm{~g}$ 이었다. 그 외에도 호흡 곤란 증후군(respiratory distress syndrome, RDS), 동맥관 개존증 (patent ductus arteriosus, $\mathrm{PDA}$ )의 동반 유무, 패혈증(sepsis)에서 양 군간 유의한 차이를 보 였으며, Grade 3 이상의 뇌실 내 출혈(intraventricular hemorrhage), 조기 양막파수(premature rupture of membrane)의 유무, 사망률에서는 두 그룹간에 유의한 차이를 보이지 않았다. 진단 시 일령에 따른 조기발생 군과 후기발생 군 간의 비교에서 양 군간 유 의한 관계가 있었던 출생체중, 재태주령, 호흡 곤란 증후군, 제왕 절개 분만, 동맥관 개존증, 패혈증에 대하여 다변량 로지스틱 회귀 분석을 시행한 결과 제왕절개 분만(OR 0.085 [95\% CI, 0.014$0.508 ; P=0.007$ ])과 재태주령 (OR 0.923 [95\% CI, 0.923-0.876; $P=0.002])$ 만이 유의한 인자였다(Tables 3, 4).

\section{고찰}

$\mathrm{NEC}$ 는 신생아 특히 미숙아에서 발생하는 장관 질환 중 가장 흔 하면서 사망률도 높은 위험한 질환이다. 오랜 기간의 많은 연구에 도 불구하고 아직 그 원인이 뚜렷이 밝혀지지 않고 있으며 수많은 요인들이 관련되어 있는 것으로 보고되고 있다1,2,18). 미숙아에서 주로 발병하며 장점막의 미숙함이 주요 요인으로 알려져 있지만 호흡곤란 증후군 및 동맥관 개존증과 같이 발달 과정의 미숙아에 국한된 질환이 아닌 $10 \%$ 정도는 만삭아에서도 발병하는 질환으 로 설명되며19) 만삭아는 미숙아에 비해 NEC의 발생이 조기에 일 어나고 재태주령과 NEC의 발생시기는 역비례 한다는 보고들이

Table 2. Distribution of Gestational Age, Birth Weight, and Age at Diagnosis according to Each Study Groups

\begin{tabular}{llcccc}
\hline \multirow{2}{*}{ Group (wks) } & $\mathrm{n}$ & Gestational age (wks) & Birth weight (g) & \multicolumn{2}{c}{ Age at diagnosis } \\
\hline$<28$ & & & & Postnatal (d) & Postmestural (wks) \\
$28-32$ & 16 & $26.3 \pm 1.1$ & $822.5 \pm 118.7$ & $31.6 \pm 27.5$ & $30.8 \pm 3.8$ \\
$33-36$ & 20 & $30.3 \pm 1.7$ & $1,278.0 \pm 265.0$ & $15.9 \pm 14.9$ & $32.6 \pm 1.7$ \\
$37-$ & 11 & $34.2 \pm 1.0$ & $1,894.5 \pm 507.6$ & $4.7 \pm 2.8$ & $34.8 \pm 0.9$ \\
\hline
\end{tabular}


Table 3. Demographic Characteristics and Clinical Outcomes of Early-Onset Necrotizing Enterocolitis and Late-Onset Necrotizing Enterocolitis Groups

\begin{tabular}{lccr}
\hline & $\begin{array}{c}\text { Early-onset } \\
\text { NEC } \\
(\mathrm{n}=29)\end{array}$ & $\begin{array}{c}\text { Late-onset } \\
\text { NEC } \\
(\mathrm{n}=20)\end{array}$ & $P$-value \\
\hline Age at diagnosis, days & $5.6 \pm 3.4$ & $36.1 \pm 22.6$ & $<0.001$ \\
Gestational age (wks) & $32.1 \pm 3.5$ & $27.4 \pm 1.8$ & $<0.001$ \\
Birth weight (g) & $1,534.1 \pm 658.0$ & $1,036.5 \pm 257.0$ & 0.001 \\
Male, n (\%) & $11(37.9)$ & $11(55.0)$ & 0.238 \\
Cesarean delivery, n (\%) & $23(79.3)$ & $4(20.0)$ & $<0.001$ \\
RDS, n (\%) & $10(35.5)$ & $14(70.0)$ & 0.015 \\
IVH $\geq$ G3, n (\%) & $5(17.2)$ & $4(20.0)$ & 0.999 \\
PDA, n (\%) & $5(17.2)$ & $10(50.0)$ & 0.014 \\
PROM, n (\%) & $8(27.6)$ & $3(15.0)$ & 0.488 \\
Sepsis, n (\%) & $3(10.3)$ & $8(72.7)$ & 0.033 \\
Outborn, n (\%) & $5(17.2)$ & $0(0.0)$ & 0.070 \\
Mortality, n (\%) & $3(10.3)$ & $4(20.0)$ & 0.422 \\
\hline Abbreviations: &
\end{tabular}

Abbreviations: NEC, necrotizing enterocolitis; RDS, respiratory distress; IVH, intraventricular hemorrhage; PDA, patent ductus arteriosus; PROM, premature rupture of membrane.

Values are expressed as number (\%) or Mean \pm SD.

Table 4. Logistic Analysis of Associated Factors for Late-Onset Necrotizing Enterocolitis

\begin{tabular}{lclc}
\hline & Odds ratio & \multicolumn{1}{c}{ CI 95\% } & $P$-value \\
\hline Gestational age & 0.923 & $0.876-0.972$ & 0.002 \\
Birth weight (g) & 1.002 & $0.998-1.006$ & 0.414 \\
Cesarean delivery & 0.085 & $0.014-0.508$ & 0.007 \\
RDS & 13.117 & $0.478-359.610$ & 0.128 \\
PDA & 4.604 & $0.218-97.219$ & 0.327 \\
Sepsis & 2.407 & $0.120-48.239$ & 0.566
\end{tabular}

Abbreviations:CI, confidence interval; RDS, respiratory distress syndrome; PDA, patent ductus arteriosus.

있어 왔다 ${ }^{4,20)}$. 그러나 재태주령에 따라 NEC의 발병시기가 차이가 나는 이유도, 미숙아나 만삭아의 NEC 병인에 어떤 차이가 있는 지 도 아직 뚜렷하게 밝혀지지 않은 실정이다.

$\mathrm{NEC}$ 는 임상 증상, 신체 검진 및 방사선학적 검사 등을 통하여 진단한다. 그 중 방사선학적 검사는 객관적으로 NEC 진단을 내릴 수 있는 도구이며, 단순 복부 $\mathrm{x}$-ray 검사와 복부 초음파를 이용한 다. 단순 방사선학 검사는 NEC 진단에 빠르고 손쉽게 이용할 수 있는 대표적인 검사로 장내 가스 분포, 장 마비 등을 확인할 수 있 으나 NEC 진단에 매우 중요한 요소인 장벽 내 공기음영을 확인하 는 것은 어렵다. 이에 비하여 복부 초음파는 문맥정맥 내 공기, 복 수(peritoneal fluid), 장벽 두께, 장벽 음영(bowel echogenicity), 장관 관류(perfusion), 장벽 내 공기(intramural gas) 등 다양한 방
법을 통해서 장의 상태를 좀 더 섬세하게 확인 할 수 있고 따라서 조기에 NEC를 진단 할 수 있다는 연구들이 보고되고 있다2,13).

저자들은 신생아 중환자실에 입원한 신생아들 중 복부팽만 및 수유진행이 어려운 환자 등 괴사성 장염이 의심되는 모든 환자들 을 대상으로 증상 초기에 복부 초음파를 시행하였고 복부 초음파 소견을 modified bell's criteria 에 적용하여 NEC stage IIA이상에 해당하는 환자를 NEC 로 진단하였다. 본 연구는 이제까지의 NEC 에 관련된 연구들이 대부분 복부 방사선촬영과 임상 증상 만으로 진단된 NEC 환자들을 대상으로 한 것과 달리 초음파를 이용하여 증상 초기에 $\mathrm{NEC}$ 를 진단하고 이들 환자들을 대상으로 재태주령 에 따른 NEC의 진단시기를 파악하여 그 발병 요인을 알기 위하여 시행하였다. 저자들의 연구 결과 초음파를 통한 NEC의 진단 시기 는 출생 시 재태주령을 기준으로 28주 미만에서 평균 31.6일, 28-32주 평균 15.9일, 33-36주 평균 4.7일, 37주 이상 평균 3.5일 이었다. 이러한 결과는 출생 시 재태주령 28 주 미만아는 평균 22 일, 28-32주 평균 13일, 33-36주 평균 4일, 37주 이상 평균 2일에 $\mathrm{NEC}$ 로 진단된 것으로 보고한 Llanos 등 ${ }^{21}$ 과 $\mathrm{NEC}$ 발생 시기를 출 생 시 재태주령 28주 미만아, 평균 18일, 28-32주 평균 12일, 3336 주 평균 10 일, 37 주 이상 평균 8 일로 보고한 Hwang 등22)이 복부 방사선 촬영으로 진단한 연구 결과와 유사한 양상을 보였다.

저자들의 연구 결과 28 주 미만 그룹에서 다른 결과들에 비하여 오히려 더 늦게 NEC 로 진단된 결과를 보였으나 출생 시 재태주령 이 어릴수록 확연하게 늦게 발병하며 만삭에 가까울수록 NEC 진 단 시점이 짧아지는 양상은 다른 보고들과 일치하였다 4,20$)$. 즉, 초 음파로 증상 초기에 $\mathrm{NEC}$ 를 진단한 결과 진단 시점은 재태주령이 어릴수록 더 늦게 발병한다는 이전 보고들과 차이가 없었다.

출생 후 NEC 의 발병일에 따라 재태주령과 출생체중과의 관련 성을 보고한 이전의 보고들에 의하면 Neu와 Walker'른 미숙아에 게 오는 "Classic" NEC는 생후 8-10일경 오고 재태주령 기준으로 32 주경 가장 많이 발병한다고 보고하였다. Yee 등23)이 Canadian neonatal network를 이용한 보고에 의하면 33주 미만에서 출생체 중 $1,000 \mathrm{~g}$ 이상 환자의 $\mathrm{NEC}$ 진단 시기가 평균 7일 이었고 $1,000 \mathrm{~g}$ 미만의 경우 평균 32일로 역시 재태주령과 출생체중은 NEC 진단 일에 역비례 한다고 하였다. Grosfeld 등ㄴ)은 25년간의 cohort결 과 $1,000 \mathrm{~g}$ 이상은 13 일에 $1,000 \mathrm{~g}$ 이하는 21 일에 진단되었다고 보 고한 바 있다. NEC 진단 시 연령을 14 일을 기준으로 조기발생 군 과 후기발생 군으로 나누어 비교한 저자들의 연구 결과에서도 조 기발생 군 29 명의 출생 시 평균 재태주령과 출생 체중은 32.1 주, $1,534.1 \mathrm{~g}$, 진단 시 평균 일령이 5.6일이었으며, 후기발생 군 20명 의 출생 시 평균 재태주령과 출생 체중은 27.4 주, $1,036.5 \mathrm{~g}$, 진단 시 평균 일령이 36.1일으로 다른 보고들과 유사하게 NEC가 조기 에 발생하는 군이 재태주령 및 출생 체중이 후기발생 군에 비하여 높은 결과를 보였다. 이와 같이 각각의 보고 별로 재태주령 간의 
$\mathrm{NEC}$ 진단 시기에 차이는 있으나 재태주령이 어릴수록 출생체중 이 작을수록 $\mathrm{NEC}$ 가 더 늦게 발병하는 양상은 차이가 없으며 초음 파를 통한 진단 시에도 이러한 양상은 같은 소견을 보였다.

과거 $\mathrm{NEC}$ 는 미숙아에서 출생 후에 장관영양을 시작한 후 발생 하는 것으로 알려져 왔달) 그러나 장관영양을 시작하지도 않은 신생아들에게도 NEC가 발병되는 빈도가 증가되고 또한 재태주령 23-28주 미숙아에서 장관영양이 시작된 수주 이후에도 NEC가 발 병된다는 보고들이 증가하면서 $\mathrm{NEC}$ 는 호흡곤란, 동맥관 개존증, 뇌실 내 출혈 등의 대표적 미숙아 질환과 다르게 발생시기를 미리 예측하기 어려운 질환으로 분류 되고 있다 ${ }^{26)}$. 재태주령 및 출생체 중에 따라 $\mathrm{NEC}$ 의 발생 시기가 다른 요인에 대한 연구들은 대부분 이 첫 수유 시기와 NEC 발생시기가 의미 있는 관계를 보인다고 하 였다. 재태주령이 어릴수록 장관수유가 늦게 시작되고 또 장관수 유가 진행되는 상태라도 장점막의 미성숙과 위축, 염증 및 세균의 증식 등으로 $\mathrm{NEC}$ 의 위험을 지속적으로 가지고 있기 때문에 장관 수유가 빠르게 시작되고 진행되는 만삭아에 비하여 미숙아에서 $\mathrm{NEC}$ 가 늦게 발병하는 것으로 설명한 바 있다 ${ }^{19)}$. 그러나 최근에 진 행된 극소저체중아를 대상으로 시행한 메타분석 ${ }^{27)}$ 에서는 조기장 관영양 및 장관영양 진행 속도가 $\mathrm{NEC}$ 발생과 연관되었다는 근거 가 없다는 연구 결과가 보고 됨으로써 상기 가설들도 확실한 이유 가 되지는 못하고 있다. 저자들의 연구 결과에서는 조기발병 군과 후기발병 군간에 재태주령, 출생체중, 제왕절개 분만, 신생아 호흡 곤란증, 동맥관 개존증, 패혈증 등이 통계적으로 유의한 차이를 보 였다. 그러나 이들 인자들에 대하여 다변량 로지스틱 회귀 분석을 시행한 결과 양 군간에 독립적으로 영향을 미치는 인자는 재태주 령과 제왕절개 분만뿐 이었다. 신생아 호흡 곤란증, 동맥관 개존 증, 패혈증의 동반 유무에서 조기 및 후기발병 군에 차이가 있는 것으로 보였으나 이는 조기 발병 군이 후기발병 군에 비하여 재태 주령이 더 높았기 때문으로 생각된다. 3 기 이상의 뇌실 내 출혈, 조 기 양막파수의 유무, 사망률에서는 두 군간에 유의한 차이를 보이 지 않았는데 조기발병 군 내에서3기 이상의 뇌실내 출혈을 동반한 경우는 모두 미숙아 혹은 분만 시 저산소증 소견을 보인 경우였고 괴사성 장염으로 인한 사망은 후기발병 군에서 1 명 있었다. 다변 량 분석에서 유의한 인자로 나타난 제왕절개 분만과 NEC 발병과 의 관련성에 대한 연구로는 2005년 Malamitsi-Puchner 등28)이 장 내 미생물이 출생 후 신생아의 면역계 발달에 중요한 영향을 미치 며 질식 분만된 신생아에서 다양한 종류의 싸이토카인이 생산되 는 것을 확인할 수 있었다고 보고하였다. 2004년 Hallstrom 등29)은 분만 방법이 NEC 발병에 미치는 영향을 미숙아를 대상으로 연구 하였으며 제왕절개로 분만된 신생아의 경우 장내 미생물의 집락 (colonization)이 교란되어 NEC 발생률이 더 높았다고 보고한바 있다. 반면 2008년 Siggers 등30)은 질식분만이 신생 초기 장관 및 대사기능의 성숙에 관련되기는 하나 소화관의 기능 및 염증 반응
은 제왕절개 분만 시와 같거나 더 늦는 경향을 보이므로 두 가지 분만방법에 따라 NEC 발병률은 유사하였다고 보고한 바 있다. 저 자들의 연구 결과는 조기발병 군에서 제왕절개 분만이 $79.3 \%$ 이었 던 반면 후기발병 군에서는 $20.0 \%$ 에 불과하여 보고된 연구 논문 들과 일치하지는 않았다. 단 출생 초기에 $\mathrm{NEC}$ 로 진단된 그룹에서 제왕절개 분만아가 많았던 것은 발병시기에 따른 병인의 차이와 관련된 추가적인 연구가 필요한 부분으로 생각된다.

결론적으로 복부 초음파를 통해 $\mathrm{NEC}$ 를 진단받은 신생아를 출 생 시 재태주령 별로 NEC 진단 시기를 나누거나, 진단 시 연령 14 일을 기준으로 조기발생 군과 후기발생 군으로 나누었을 때 만삭 아 혹은 만삭아에 가까운 미숙아일수록 NEC의 발생률은 줄지만 더 빠른 시기에 발병한다는 것을 알 수 있었다. 따라서 만삭아 및 준 만삭아 에서 NEC가 의심되는 임상 소견을 보일 경우 출생 후 수일 내에 NEC 가 일어날 수 있으므로 초음파 등의 검사를 이용하 여 빠른 진단 및 치료가 이루어져야 할 것으로 생각한다. 또한 재 태주령에 따른 NEC 발병 시기의 차이와 관련된 인자로 분만 방법 이 제시되었으나 이와 관련되어서는 추후 좀 더 많은 NEC 환자들 을 대상으로 분만 방법과 NEC 발병 시기의 관련성에 대한 추가적 인 연구가 필요할 것으로 생각된다.

\section{REFERENCES}

1) Lin PW, Stoll BJ. Necrotising enterocolitis. Lancet 2006;368: 1271-83.

2) Neu J, Walker WA. Necrotizing enterocolitis. N Engl J Med 2011;364:255-64.

3) Kim JK, Kim YS, Yoo HS, Ahn SY, Choi SH, Seo HJ, et al. Analysis of prognostic factors of laparotomy for necrotizing enterocolitis in extremely low birth weight infants. Korean J Pediatr 2010;53:167-72.

4) Stoll BJ. Epidemiology of necrotizing enterocolitis. Clin Perinatol 1994;21:205-18.

5) Moss RL, Dimmitt RA, Barnhart DC, Sylvester KG, Brown RL, Powell DM, et al. Laparotomy versus peritoneal drainage for necrotizing enterocolitis and perforation. N Engl J Med 2006; 354:2225-34.

6) Huda S, Chaudhery S, Ibrahim H, Pramanik A. Neonatal necrotizing enterocolitis: clinical challenges, pathophysiology and management. Pathophysiology 2014;21:3-12.

7) Bell MJ, Ternberg JL, Feigin RD, Keating JP, Marshall R, Barton L, et al. Neonatal necrotizing enterocolitis. Therapeutic decisions based upon clinical staging. Ann Surg 1978;187:1-7.

8) Walsh MC, Kliegman RM. Necrotizing enterocolitis: treatment based on staging criteria. Pediatr Clin North Am 986; 33:179-201 
9) Bunomo C. The radiology of necrotizing enterocolitis. Radiol Clin A Am 1999;37:1187-98.

10) Franco A, Ramji FG. Utility of abdominal sonography to diagnose necrotizing enterocolitis. Eur J Radiol Extra 2008; 65:13-6.

11) Weinberg B, Peralta VE, Diakoumakis EE, Shah KD, Mollin J, Jhaveri MK, et al. Sonographic findings in necrotizing enterocolitis with paucity of abdominal gas as the initial symptom. Mt Sinai J Med 1989;56:330-3.

12) Kim WY, Kim WS, Kim IO, Kwon TH, Chang W, Lee EK. Sonographic evaluation of neonates with early-stage necrotizing enterocolitis. Pediatr Radiol 2005;35:1056-61.

13) Bohnhorst B. Usefulness of abdominal ultrasound in diagnosing necrotizing enterocolitis. Arch Dis Child Fetal Neonatal Ed 2013;98:F445-50.

14) Kobayashi M, Mizuno M, Matsumoto A, Wakabayashi G. Neonatal portal venous blood flowmetry by doppler ultrasound for early diagnosis of ischemia in intestinal tract. Eur J Pediatr Surg 2014 Epub 2014 Mar 12. doi:10.1055/s-00341374820.

15) Gane B, Bhat BV, Adhisivam B, Joy R, Prasadkumar P, Femitha $\mathrm{P}$, et al. Risk factors and outcome in neonatal necrotising enterocolitis. Indian J Pediatr 2014;81:425-8.

16) Sylvester KG, Ling XB, Liu GY, Kastenberg ZJ, Ji J, Hu Z, et al. Urine protein biomarkers for the diagnosis and prognosis of necrotizing enterocolitis in infants. J Pediatr 2014;164:607-12. el-7.

17) Papile LA, Munsick-Bruno G, Schaefer A. Relationship of cerebral intraventricular hemorrhage and early childhood neurologic handicaps. J Pediatrics 1983;103:273-7.

18) Shim SY, Jung KE, Kim ES, Lee JA, Kim EK, Kim HS, et al. Clinical characteristics and predisposing factors in full-term and preterm neonates with necrotizing enterocolitis. J Korean Soc Neonatol 2005;12:79-86

19) Wiswell TE, Robertson CF, Jones TA, Tuttle DJ. Necrotizing enterocolitis in full-term infants. A case-control study. Am J Dis Child 1988;142:532-5.

20) Ostlie DJ, Spilde TL, St Peter SD, Sexton N, Miller KA, Sharp RJ, et al. Necrotizing enterocolitis in full-term infants. J Pediatr Surg 2003;38:1039-42.

21) Llanos AR, Moss ME, Pinzòn MC, Dye T, Sinkin RA, Kendig
JW. Epidemiology of neonatal necrotising enterocolitis: a population-based study. Paediatr Perinat Epidemiol 2002;16: 342-9.

22) Hwang JH, Choi CW, Chang YS, Park WS. Epidemiology of neonatal necrotizing enterocolitis: a 8-year experience. J Korean Soc Neonatol 2003;10:178-84.

23) Yee WH, Soraisham AS, Shah VS, Aziz K, Yoon W, Lee SK. Incidence and timing of presentation of necrotizing enterocolitis in preterm infants. Pediatrics 2012;129:e298-304.

24) Grosfeld JL, Cheu H, Schlatter M, West KW, Rescorla FJ. Changing trends in necrotizing enterocolitis. Experience with 302 cases in two decades. Ann Surg 1991;214:300-6; discussion 6-7.

25) Kamitsuka MD, Horton MK, Williams MA. The incidence of necrotizing enterocolitis after introducing standardized feeding schedules for infants between 1250 and 2500 grams and less than 35 weeks of gestation. Pediatrics 2000;105:37984.

26) Morgan J, Bombell S, McGuire W. Early trophic feeding versus enteral fasting for very preterm or very low birth weight infants. Cochrane Database Syst Rev 2013:Cd000504. doi: 10.1002/14651858.CD000504.pub4.

27) Morgan J, Young L, McGuire W. Slow advancement of enteral feed volumes to prevent necrotising enterocolitis in very low birth weight infants. Cochrane Database Syst Rev 2013: Cd001241. doi: 10.1002/14651858.CD001241.pub4.

28) Malamitsi-Puchner A, Protonotariou E, Boutsikou T, Makrakis E, Sarandakou A, Creatsas G. The influence of the mode of delivery on circulating cytokine concentrations in the perinatal period. Early Hum Dev 2005;81:387-92.

29) Hallstrom M, Eerola E, Vuento R, Janas M, Tammela O. Effects of mode of delivery and necrotising enterocolitis on the intestinal microflora in preterm infants. Eur J Clin Microbiol Infect Dis 2004;23:463-70.

30) Siggers RH, Thymann T, Jensen BB, Mølbak L, Heegaard PM, Schmidt M, et al, Elective cesarean delivery affects gut maturation and delays microbial colonization but does not increase necrotizing enterocolitis in preterm pigs. Am J Physiol Regul Integr Comp Physiol 2008;294:R929-38. 